port and advice and by supplying project leadership; also environmental training in technical skills as well as in areas of endeavour such as leadership development, and by creating opportunities for volunteer exchanges to take place.

Other projects which are already being planned through the ICAN initiative include:

- Setting up a series of practical projects in conjunction with local partners in Iceland, Portugal, Spain, Greece, and Germany - ranging from building board-walks beside geysers to helping to preserve the habitats of the rare Griffon Vulture (Gyps falous).

- CAPS 1993 - a project linking channel-coast counties or départements in England and France if they are affected by the Channel Tunnel (Transmanche) and addressing the environmental implications of the 'Chunnel'.
- Helping other European environmental organizations by lending experienced volunteers for projects such as conducting a public awareness campaign about the threatened Loggerhead Sea turtle (Caretta caretta) on the Greek island of Zákynthos. $†$

- Helping to set up a conservation volunteer organization on similar lines to BTCV in Eire.

ANITA PROSSER, International Development Officer British Trust for Conservation Volunteers (BTCV) 36 St Mary's Street

Wallingford

Oxfordshire OX10 OEU

England, UK.

†See, for example, the account by Dr Margarita Arianoutsou published in our Winter issue of 1988 - 15(4), pp. 327-34 with 11 figs, 1988.-Ed.

\title{
Conservation Activities Initiated by the International Society of Naturalists (INSONA)
}

During the course of the past year - their first of operation as an international body - INSONA has carried out intensive and extensive conservation actions on various aspects of environment and wildlife maintenance. The main activities centred around due recognition of Earth Day, World Forestry Day, World Environment Day, Van Mahotsava, Wildlife Week, World Food Day, and the Environment Month. The target groups include schoolchildren, university students, the populace in general, and decision-makers, special stress being placed on involving Women with Environment.

The following are some of the various activities undertaken by INSONA during its first year of operation as an INGO:

- Competitions on environment for uncared children, the theme being 'Trees as our Friends'.

- Field trips for Nature observation in wildlife habitats and sanctuaries.

- Competition for university students to make an inventory of the migrant and local bird species in Sunderpura Blackbuck preserve near Baroda.

- Support of the Asian Crane Conference held at Rajkot, Saurashtra, in December 1989.

- Release of a book on Paryavaran (Environment) vital issues for human welfare - in the local language (Gujarati).

- A competition for women to recognize and know forest products used in our day-to-day life.

- Competitions for schoolchildren - identifying wildlife through pictures and sporting garments depicting wildlife (wildlife awareness through art).

- Essay competition for schoolchildren on 'Environmental Care for Human Welfare'.

- Establishment of a nursery to present, gratis, saplings (tens of thousands) to members of the Society, educational institutions, industrial estates, and the farming community.

- As an integral part of the National Environmental Awareness Campaign (NEAC) 1989, INSONA and Nari Samrakshan Gruh, Nizampura, nourished saplings. On one occasion a debating competition was organized on a theme of "The Role of Women in the Protection of Trees'.

- During the NEAC 1989, a competition was organized for women to promote wildlife conservation. Women and university students sported sarees and garments depicting wildlife (mammals, birds, flowers, trees, etc.).

- Organization of an elocution contest for women on the

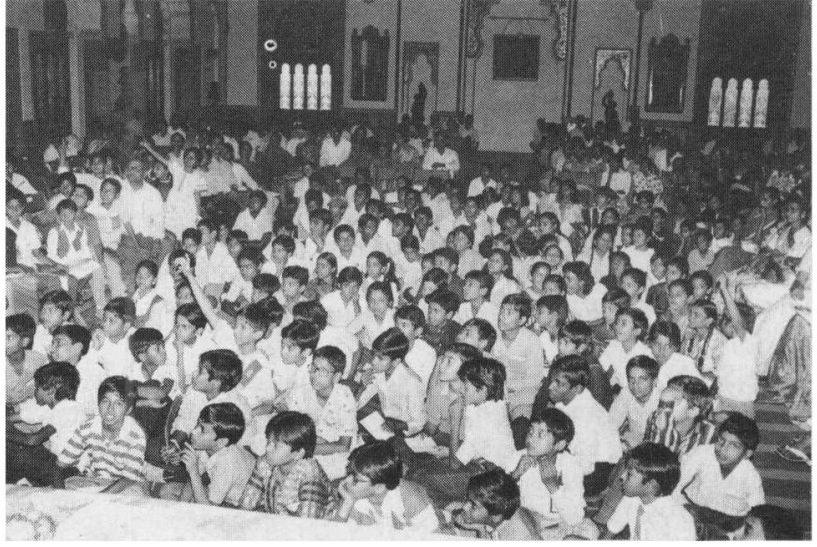

FIG. 1. Peoples' involvement in the environmental movement: a keen audience of mostly young people. Photo: Preeti Photographers.

theme of 'Environmental Conservation and National Prosperity'.

- Publications of special issues of its quarterly journal - Environmental Awareness - stressing CITES, World Food Day, Wetlands, and planning a special issue stressing Earth Day 1990.

- Bringing out stickers on the campaign 'Save Our Biosphere', highlighting the Blackbuck, and 'Johnny Biosphere'. With the help of Dr J.R. Vallentyne, the stickers are to be distributed world-wide.

- Bringing out Greetings Cards on threatened wildlife to further the cause of the Save Our Biosphere campaign as part of The World Campaign For The Biosphere.

- Requesting religious leaders of different faiths to highlight, in their sermons and otherwise, the vital importance of the Environment and saving natural habitats and wildlife.

- Organization of an exhibition on Conservation of Water at Silaj Village near Ahmedabad for the benefit of rural and urban communities.

- Organization of an exhibition of Man \& Biosphere (UNESCO's Ecology in Action Exhibit) at the Gujarat Vidyapeeth, Ahmedabad, during the All India Social Science Congress. The delegates from different States especially benefited from the exhibit on Conservation of Water. 


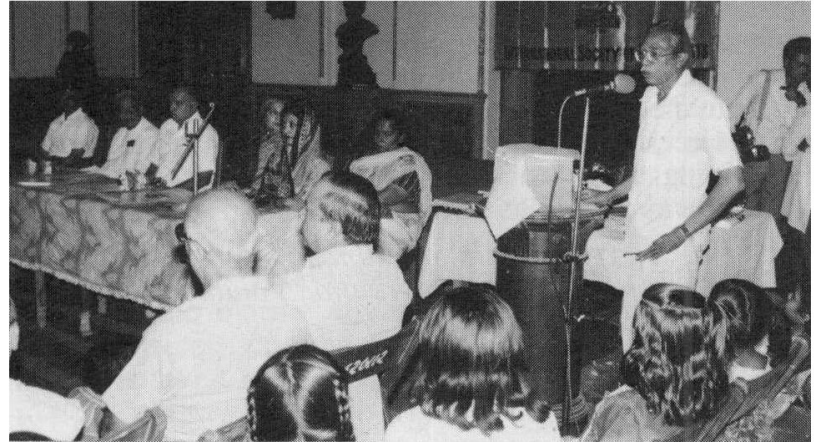

FIG. 2. General Secretary Dr G.M. Oza addressing an 'environmental archivers' meeting of INSONA, with the base of the Society's emblem visible behind him. Photo: Preeti Photographers.

- Members of INSONA gave broadcast talks on the environmental and conservational movements.

- Programmes on Doordarshan Kendra Srinagar and Ahmedabad were given on 'The Role of CITES' (Convention on International Trade in Endangered Species of Fauna and Flora) and 'Illegal Trade in Global Wildlife'.

- Talks on Environment (with AV aids) in various schools for the benefit of both pupils and teachers. On these and more public occasions the audience was often large and enthusiastic (Fig. 1).

- The Press was briefed at regular intervals on environmental issues.

- Skating for Environmental Awareness by hundreds of students.

- INSONA was a partner in the campaign to save the African Elephant (Loxodonta africana). The impact was felt in the CITES Conference through more than one thousand signatures supporting the pledge not to use or promote tusk products.

- Survey of the Bharatpur Kaleodeo National Park to determine the environmental status of the cranes and their habitat.

- Designing of special T-Shirts - on Save Our Biosphere and Environmental Awareness highlighting the Indian Tiger (Felis tigris) and the Blackbuck (Antilope cervicapra).

- Talks delivered by Professor T.A. Davis on 'Man and Nature' and 'the Palms of the World'. These are in addition to 'archivers' and other meetings of INSONA (Fig. 2).

- Competition for schoolchildren to design posters on the well-being of the Earth.

It is hoped that the above gives a fair indication of the range of what can be done by an international concern in its home country despite very limited resources as it feels its way towards wider influence.*

\section{Gunavant M. Oza, General Secretary \\ International Society of Naturalists (INSONA) Indumati Mahal \\ Jawaharlal Nehru Marg \\ Baroda 390 001, India.}

\begin{abstract}
*As, originally, the Indian Society of Naturalists, INSONA was established in the year 1975 by the former Maharaja of Baroda, the late Fatehsinghrao P. Gaekwad, as its Founding President, and with Dr Gunavant M. Oza as its Founding General Secretary. For the past 15 years, the latter has spearheaded various activities, campaigns, and crusades, on behalf of INSONA and such affiliates as our Foundation for Environmental Conservation, aimed at the common well-being of Mankind and Nature. A notable example of such collaboration is the World Campaign for The Biosphere, and an outcome of Dr Oza's personal dedication is the quarterly journal Environmental Awareness, which now has an impressive supporting panel of internationally-known Consulting Editors.

Mrs Premlata Oza, Joint Secretary of INSONA, has extended several aspects of the environmental and conservational movements to schoolchildren and women in India, in a manner that should set a worthy example for other countries and regions. - Ed.
\end{abstract}

\section{Maurice Strong to be Secretary-General of the UN Conference on Environment and Development}

The Secretary-General of the United Nations has announced the appointment of Maurice F. Strong as Secretary-General of the United Nations Conference on Environment and Development, to be convened in 1992 in accordance with General Assembly resolution 44/228. Mr Strong, who was our first Baer-Huxley Memorial Lecturer in Iceland in 1977, informed us very recently that this major event, '20 years after Stockholm', would be in Brazil, although it had not yet been decided precisely where in that vast country.

Mr Strong is currently Chairman of Stroevest Holdings in Canada, Chairman of the Council of the World Economic Forum, Geneva, and President of the World Federation of United Nations Associations. From 1985 to 1986, he was Executive Coordinator of the United Nations Office for Emergency Operations in Africa. More pertinently, he was Secretary-General of the 1972 United
Nations Conference on the Human Environment (in Stockholm, Sweden) and subsequently became the first Executive Director of the United Nations Environment Programme.

Maurice Strong's work in development has included heading-up Canada's International Development Assistance Agency, and service as Alternate Governor of the World Bank, the Asian Development Bank, and the Caribbean Development Bank. He has also been President and Chairman of the Board of Petrocanada as well as Chairman or Director of various Canadian and international corporations. Again more pertinently he was a member of the World Commission on Environment and Development and Chairman of the Bureau of IUCN.

Born in 1929 in Manitoba, he is married to Hanne Marstrand, from Denmark.-Ed.

\section{Euro Citizen Action Service}

Euro Citizen Action Service (ECAS) is being set up as a non-profit-making service to inform, advise, and strengthen, thie position of voluntary-sector NGOs in relation to European Community (EC) institutions. It seeks to involve the 'Citizens of Europe' in European affairs, through their membership of organizations in major fields such as health, the environment, human rights, and development.

Whilst there are about 3,000 'watchers' of the EC, few work for public-interest concerns. This imbalance is 